\title{
Nature of chemical composition diversity of the East Ttransbaikalia salt lakes (Russia)
}

\author{
Svetlana Borzenko ${ }^{1, *}$ \\ ${ }^{1}$ Institute of Natural Resources, Ecology and Cryology in the Siberian Branch of the Russian \\ Academy of Sciences, 672002, Chita, Nedorezova 16a, Russia
}

\begin{abstract}
We have developed a new concept for the formation of geochemical types of salt lakes-which explains the nature of their different chemical composition under close landscape-climatic and geologicalgeochemical conditions. The extensive field hydrogeochemical material and thermodynamic calculations demonstrate that in addition to evaporation, the interaction with rocks plays a great role in the formation of the composition of lakes. This interaction begins in the catchment area of a particular lake and continues directly in the lake. Such processes are most widespread in soda lakes, which is confirmed by the presence of the highest $\mathrm{pH}$ values (9.0-10.7). Besides, one of the most important processes is sulfate reduction, which results in hydrogen sulphide in lakes fundamentally changes the geochemical environment from oxidizing to reducing one and leads to a change in the oxidation state of many elements, changing their migration ability and, therefore, the ability for concentration or binding by secondary minerals. The presence of an oxidizing environment and sulphides in rocks gives additional sources for sulfates, which ensures the formation of sulfate-type lakes.
\end{abstract}

\section{Introduction}

Historically, chemists studied the chemistry of salt lakes and associated salts and they explained their high salinity mainly by evaporation of sea water. This research area is primarily associated with the name of the Netherlands chemist Jacobus H. Van't Hoff, he and his students dealt with ancient salt basins [1]. In Russia, and later in the USSR scientists examined the salts of the present-day lakes of the Crimea Peninsula, the Volga region, the Caspian area, and Siberia, which were more accessible for study [2]. N.M. Strakhov [3] considered the problem of salt formation as a part of lithological processes. P. Sonnenfeld [4] develops a geological-geographical approach to determine leading factors in the formation of brines and evaporites. At the end of XX century the new direction of research on thermodynamic modelling of phase processes in water-salt systems of lakes has appeared and is actively developing recently [5]. Great contribution to the development of modelling methods was made by French scientists who studied many salt lakes in France [6, 7 etc.]. All these studies have revealed one important circumstance: a variety of geochemical types of lakes are typically developed in every sufficiently limited area under

*Corresponding author: svb_64@mail.ru 
similar landscape-climatic and geological-geomorphological conditions. It is typical for any region of the world - Africa, Australia, China, Mongolia, the Crimea Peninsula, the Western Siberia, and the Baikal region [8, 9, 10, 11, etc.] The same diversity of lakes is typical for the Transbaikalia region[12,13, 14]. Therefore, the main purpose of this work is to reveal the factors and mechanisms that determine the diversity of the composition of saline lakes in the East Transbaikalia.

\section{Area of Study}

A lot of brackish and salt lakes are very common in the territory of the East Transbaikalia. All of them are confined to the forest-steppe and steppe landscapes and climatic zones and located in the basins of the Ingoda River, the Onon River, and also within the Torey drainage basin. The relief of the region is mainly low-mountainous, hollow-hilly and plain. In the basin of the Ingoda River there are ridges up to $1300 \mathrm{~m}$. The minimum mark $(596 \mathrm{~m})$ is in the area of Zun-Torey Lake. A considerable part of the area is occupied by the OnonTorey plain, which is cut by shallow creek valleys, where numerous lakes are located. Most of them are located within the Tsasucheyskaya Depression. The rocks are represented mainly by clayey shales and sandstones with the interlayers of effusive basalts. Metamorphic fossils of the Paleozoic with clayey shales, gneisses, limestones, mudstones and siltstones broken by the Mesozoic granites are found in the margins of the basin [15].The climate of the region is sharply continental. A thin snow cover is formed in early November and thaws at the end of April before the ice melts, so there is practically no water supply with thawed snow to the reservoirs. The annual amount of precipitation is almost two times lower than the evaporation.

The studied lakes are reservoirs with different morphometric characteristics. Most lakes belong to small water bodies (small in area and shallow in depth) with significant variations in the areas of water tables (from 0.01 to $580 \mathrm{~km}^{2}$ ) and their watersheds (from 1 to 25,100 $\mathrm{km}^{2}$ ), as well as depths (from 0.1 to $7.5 \mathrm{~m}$ ) (Table 1). A common feature of all lakes is that they are drainless. The calculations of the water balance of ten lakes have shown that the difference between water input and output for larger lakes is less than for small lakes. The analysis of the dependence between salinity and water volumes has shown that it increases to $15 \mathrm{~g} / \mathrm{L}$ for lakes with a water volume from 1 to $10^{-3} \mathrm{~km}^{3}$, and it can reach $50 \mathrm{~g} / \mathrm{L}$ and more at lower volumes.

\section{Results}

As the data in Table 1 show, the chemical composition, salinity (you can use salinity/mineralization but more common: Total dissolved Solids-TDS), and geochemical environment of the studied lakes are quite diverse. The salinity varies from 1.2 to $343 \mathrm{~g} / \mathrm{L}$, the $\mathrm{pH}$ ranges from 7.41 to 10.74 , and the Eh from -423 to $281 \mathrm{mV}$. The contents of all elements also vary widely, although $\mathrm{Ca}$ and $\mathrm{Mg}$ concentrations always remain relatively low. It is necessary to classify lakes depending to their chemical parameters. It is usual practice to subdivide lakes only according to leading anions and cations, or rather to their ratios $[16,17]$, and such important indicators as salinity, $\mathrm{pH}$, Eh and other parameters are not used in these chemical classifications. Geochemical classifications for lake waters have not yet been developed. In this situation we decided to include lakes with a $\mathrm{pH} \geq 9.0$ in the soda-type lakes, since they are indeed soda-type lakes, although chloride ion is often dominant among the anions. If the water has a $\mathrm{pH}<9.0$, then in this case they are divided into types according to a dominant anion. This approach made it possible to distinguish three types of lake waters in the region: soda, chloride and sulfate waters, and soda waters 
are divided into 3 subtypes also by the prevailing anion. The first subtype includes lakes with the predominance of hydrocarbonate and carbonate ions, the second subtype with the predominance of sulfate ions and the third subtype with the predominance of chloride ions. This approach allowed us to define the mechanisms controlling the features of the composition and formation of lake waters.

It is very difficult to trace relationships between $\mathrm{pH}$ and salinity without division of lakes into categories, but with our classification the picture becomes clear (Fig. 1 a). In this case it is obvious that in soda lakes the $\mathrm{pH}$ of the water increases with increasing salinity, while it decreases in chloride and sulfate lakes. If we take into account that in case of simple evaporation of any water, its $\mathrm{pH}$ decreases [18], then the observed dependence gets a genetic explanation. Simultaneously, the fact that the $\mathrm{pH}$ values are correlated with the

Table 1. The main chemical parameters of saline lakes of the East Transbaikalia according to selected types.

\begin{tabular}{|c|c|c|c|c|c|c|c|c|c|c|}
\hline \multirow{2}{*}{ Parameters } & \multirow{2}{*}{$\begin{array}{c}\text { Unit } \\
\mathrm{s}\end{array}$} & \multicolumn{3}{|c|}{$\begin{array}{c}\text { Soda-type, average, } \\
n=84\end{array}$} & \multicolumn{3}{|c|}{ Sulfate-type, $n=3$} & \multicolumn{3}{|c|}{ Chloride-type, $n=10$} \\
\hline & & $\begin{array}{l}\text { mea } \\
\mathrm{n}\end{array}$ & $\min$ & $\max$ & $\begin{array}{c}\text { mea } \\
n\end{array}$ & $\min$ & $\max$ & $\begin{array}{c}\text { mea } \\
\mathrm{n}\end{array}$ & $\min$ & $\max$ \\
\hline Surfacearea & $\mathrm{km}^{2}$ & 7.5 & 0.3 & 260.0 & 2.4 & 0.4 & 7.27 & 0.83 & 0.2 & 1.67 \\
\hline Depth & $\mathrm{m}$ & 2.1 & 0.5 & 8.0 & 1.5 & 0.5 & 4.4 & 0.8 & 0.2 & 1.9 \\
\hline $\mathrm{pH}$ & - & 9.53 & 9.02 & 10.74 & 8.74 & 8.32 & 8.90 & 8.17 & 7.40 & 8.70 \\
\hline Eh & $\mathrm{mV}$ & 75 & -423 & 281 & 120 & 104 & 180 & 53 & -10 & 98 \\
\hline $\begin{array}{l}\mathrm{CO}_{3}^{2-} \\
+\mathrm{HCO}_{3}{ }^{-}\end{array}$ & \multirow{9}{*}{$\mathrm{g} / \mathrm{L}$} & 3.10 & 0.05 & 30.00 & 0.81 & 0.07 & 1.80 & 0.50 & 0.06 & 2.10 \\
\hline $\mathrm{SO}_{4}{ }^{2-}$ & & 2.20 & 0.01 & 62.00 & 2.90 & 0.49 & 7.60 & 3.50 & 0.21 & 14.00 \\
\hline $\mathrm{Cl}^{-}$ & & 4.20 & 0.03 & 134.00 & 0.90 & 0.27 & 2.10 & 17.8 & 1.20 & 101.0 \\
\hline $\mathrm{F}^{-}$ & & 0.01 & 0.01 & 0.41 & 0.02 & 0.01 & 0.05 & 0.07 & 0.01 & 0.04 \\
\hline $\mathrm{Ca}^{2+}$ & & 0.02 & 0.001 & 0.08 & 0.05 & 0.01 & 0.08 & 0.10 & 0.01 & 0.620 \\
\hline $\mathrm{Mg}^{2+}$ & & 0.07 & 0.001 & 0.400 & 0.06 & 0.03 & 0.09 & 0.62 & 0.01 & 3.80 \\
\hline $\mathrm{Na}^{+}$ & & 5.10 & 0.27 & 125.00 & 2.20 & 0.39 & 5.40 & 13.0 & 1.35 & 65.00 \\
\hline $\mathrm{K}^{+}$ & & 0.06 & 0.002 & 0.44 & 0.020 & 0.01 & 0.04 & 0.08 & 0.01 & 0.24 \\
\hline TDS & & 15.0 & 1.2 & 343.0 & 6.9 & 1.8 & 17.0 & 35.0 & 4.6 & 185.0 \\
\hline $\mathrm{Si}$ & \multirow{8}{*}{$\begin{array}{c}\mathrm{mg} / \\
\mathrm{L}\end{array}$} & 5.5 & 2.3 & 22.0 & 3.6 & 2.9 & 4.1 & 3.6 & 3.4 & 4.5 \\
\hline $\mathrm{Al}$ & & 0.35 & 0.01 & 17.00 & 0.20 & 0.07 & 0.40 & 0.13 & 0.02 & 0.42 \\
\hline $\mathrm{Fe}$ & & 0.440 & 0.001 & 18.000 & 0.23 & 0.08 & 0.39 & 0.08 & 0.01 & 0.26 \\
\hline As & & 0.42 & 0.01 & 6.00 & 0.07 & 0.03 & 0.14 & 0.10 & 0.01 & 0.28 \\
\hline $\mathrm{Br}$ & & 30.0 & 0.03 & 624.0 & 5.0 & 2.1 & 10.0 & 84.0 & 11.0 & 369.0 \\
\hline $\mathrm{Sr}$ & & 0.55 & 0.07 & 9.20 & 0.59 & 0.24 & 0.97 & 4.4 & 0.13 & 19.00 \\
\hline Mo & & 0.12 & 0.03 & 3.00 & 0.07 & 0.02 & 0.16 & 0.09 & 0.02 & 0.38 \\
\hline $\mathrm{U}$ & & 0.22 & 0.03 & 11.00 & 0.07 & 0.01 & 0.14 & 0.08 & 0.02 & 0.25 \\
\hline Th & \multirow{8}{*}{$\mu \mathrm{g} / \mathrm{L}$} & 2.90 & 0.01 & 209.00 & 0.20 & 0.03 & 0.53 & 0.04 & 0.01 & 0.10 \\
\hline $\mathrm{Li}$ & & 107 & 2.0 & 646.0 & 157.0 & 85.0 & 242.0 & 269 & 62.0 & 1470 \\
\hline $\mathrm{Ni}$ & & 8.14 & 0.94 & 243.47 & 16.75 & 5.00 & 24.48 & 4.94 & 1.18 & 8.14 \\
\hline $\mathrm{Cu}$ & & 27.0 & 0.79 & 437.5 & 140.0 & 9.50 & 236.2 & 6.01 & 1.90 & 27.04 \\
\hline $\mathrm{Rb}$ & & 5.6 & 0.4 & 53.0 & 5.7 & 2.5 & 10.0 & 7.5 & 1.3 & 25.0 \\
\hline $\mathrm{Zr}$ & & 50.0 & 0.1 & 1104.0 & 2.0 & 0.7 & 4.5 & 7.8 & 0.1 & 48.0 \\
\hline$\sum$ REE & & 8.3 & 0.4 & 109.0 & 0.9 & 0.8 & 1.0 & 0.7 & 0.1 & 2.5 \\
\hline $\mathrm{S}^{2-}$ & & 508 & 5 & $370.2^{*}$ & 19 & $<5$ & 27.8 & 469 & $<5$ & 1250 \\
\hline $\mathrm{SO}_{4} / \mathrm{Cl}$ & - & 0.57 & 0.01 & 5.85 & 1.54 & 1.21 & 2.05 & 0.15 & 0.1 & 0.26 \\
\hline$\delta^{34} S^{6+}$ & \multirow{2}{*}{$\%$} & 15.9 & -8.4 & 27.4 & 7.7 & 1.1 & 9.3 & 18.2 & 16 & 22.1 \\
\hline$\delta^{34} S^{2-}$ & & -13 & -31 & 13 & - & - & - & -2.8 & -5.6 & 1.2 \\
\hline $\mathrm{DE}^{* *}$ & & 141 & 2 & 2218 & 18 & 4 & 33 & 722 & 44 & 3744 \\
\hline
\end{tabular}


carbonate content is also explained; as the degree of evaporation increases, the content of carbonate ions decreases, and the content of lake waters with aluminosilicate and carbonate rocks increases with the growing of their interaction (Fig. 1b). This dependence follows from the hydrolysis of aluminosilicates [19].

a

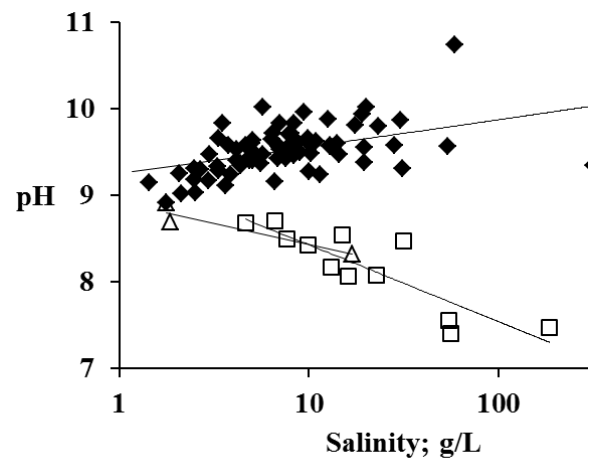

b

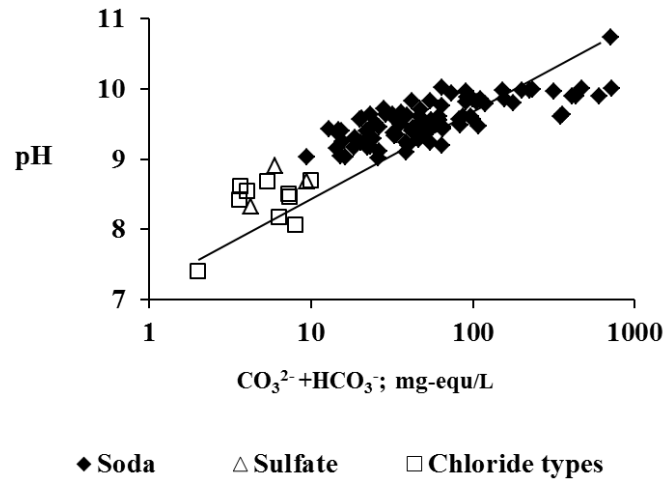

Fig. 1. Relationships between $\mathrm{pH}$ and salinity (a); between $\mathrm{pH}$ and the sum of carbonate ions of lake waters within a study area (b)

The analysis of the obtained data showed that sodium is dominant among the cations and its concentration grows in all identified types and subtypes of lakes. In chloride and sulfate lakes carbonates are not accumulated with increasing salinity, while their content in soda lakes steadily increases. At the same time, concentrations of chloride and sulfate ions are increasing everywhere. However, the growth of chloride ions, with the exception of sulfate and soda lakes of the subtype II, is significantly ahead of the growth of sulfate ions. The value of $\mathrm{SO}_{4} / \mathrm{Cl}$ ratio in soda lakes is 0.57 , in chloride lakes -0.15 and in sulfate and soda lakes of subtype II exceeds 1.0 and ratio is 1.54 and 2.14, respectively (Table 1). This circumstance shows that in most lake waters in the process of evaporation this ratio is imbalanced. The nature of this phenomenon will be considered below.

All the lake waters of the region are rich in a large complex of trace elements. The contents of $\mathrm{Br}, \mathrm{U}, \mathrm{As}, \mathrm{Mo}, \mathrm{Th}, \mathrm{Li}, \mathrm{Zn}, \mathrm{Cu}, \mathrm{Sr}, \mathrm{REE}, \mathrm{Rb}$ and other elements are much higher compared to their contents in the groundwater within a study area. But the degree of their concentration is different in different types of lakes. U, As, Mo, Th, F, Zr, REE are mostly concentrated in soda lakes, $\mathrm{Br}, \mathrm{Sr}, \mathrm{Li}, \mathrm{Rb}$ in chloride lakes, $\mathrm{Cu}, \mathrm{Ni}, \mathrm{Zn}$ in sulfate lakes. The maximum contents of some of these microcomonents are exceptionally high $(\mathrm{mg} / \mathrm{L}): \mathrm{Br}$ 624; F 410; Sr19; As 6.0; Mn 4.0; Mo 3.0; U 11; Zn 2.3; Li 1.4; Zr 1.0; Cu 0.4; Ni 0.24; Th 0.21 ; $\mathrm{Rb} 0.05$, etc. Many of these elements show close links with the content of carbonate, sulfate or chloride ions.

\section{Discussion}

The analysis of thermodynamic equilibria of lake and ground waters with the leading minerals of the watersheds and bottom sediments was performed taking into account the migration patterns of chemical elements and their contents, $\mathrm{pH}$, Eh and the temperature of geochemical environment. We have calculated the saturation indices of the solutions with respect to each mineral. An analysis of the data obtained indicates that all lake waters, irrespective of their salinity and $\mathrm{pH}$, are saturated in calcite. Most of the lake waters are saturated in dolomite and magnesite, except several points with low mineralized waters, their salinity is less than $1.5 \mathrm{~g} / \mathrm{L}$. The waters of soda lakes and, more rarely, chloride lakes are in equilibrium with strontianite; in sulfate lakes equilibrium is not achieved. Saturation 
in gaylussite and natron is achieved only in soda lakes with the salinity above 15 and 130 $\mathrm{g} / \mathrm{L}$. The most mineralized (more than $10 \mathrm{~g} / \mathrm{L}$ ) soda lakes containing more than $20 \mathrm{mg} / \mathrm{L}$ of $\mathrm{F}^{-}$are in equilibrium with fluorides, in particular with fluorite.

Consequently, as the salinity of lakes grows, the number of carbonate minerals saturated in an aqueous solution increases. The equilibrium of cations with transitional valence is determined by geochemical environment. Therefore, equilibrium with siderite is observed only in reducing conditions. However, almost all lakes are non-equilibrium with sulfate minerals, in particular, gypsum, mirabilite, blödite, glauberite and epsomite. Equilibrium with gypsum is reached in the chloride Bilchir-Nuur Lake with the sulfate ion content 8.8 $\mathrm{g} / \mathrm{L}$ and calcium $0.6 \mathrm{~g} / \mathrm{L}$. The waters of the soda Borzinskoye Lake are in equilibrium with mirabilite with a sulfate-ion content $62 \mathrm{~g} / \mathrm{L}$ and sodium $125 \mathrm{~g} / \mathrm{L}$.

The presence of hydrogen sulphide in lakes contributes to the formation of various iron sulphides: hydrotroilite and pyrite. Under oxidizing conditions, the formation of a wide range of different oxides and hydroxides, primarily iron, is thermodynamically advantageous. There is no equilibrium with chloride salts, hydrogalite and halite in any lakes.

In addition to the secondary carbonate and sulfate minerals considered, the equilibrium of water with aluminosilicate and silicate minerals was studied. According to our calculations, all lake waters are oversaturated in kaolinite, montmorillonites of various composition and illite, i.e. minerals that mainly develop in the weathering crust during the early formation stages under condition: TDS $>1.2 \mathrm{~g} / \mathrm{L}$ and $\mathrm{pH}>7.4$. With increasing salinity (more than $3 \mathrm{~g} / \mathrm{L}$ ) and $\mathrm{pH}$ (more than 8.6) of water, equilibrium is established with atypical for the zone hypergenesis autigenic minerals: analcime, Mg-chlorite, muscovite, prehnite, and others, i.e. minerals, which are usually formed in hydrothermal conditions.

Such equilibrium is primarily characteristic for soda lakes and it is rarely for chloride and sulfate lakes. Thus, chloride lakes with mineralization of 6-10 g/L get into the equilibrium field of prehnite. It is important to note that achieving in soda lakes water balance with this mineral becomes possible with a lower salinity, starting at $3 \mathrm{~g} / \mathrm{L}$. Only waters of soda lakes with $\mathrm{pH}>9.5$ and salinity more than $10-15 \mathrm{~g} / \mathrm{L}$ are in equilibrium with laumontite and albite.

However, all underground and lake waters, including brines, remain unbalanced to a large group of primary minerals - fayalite, anorthite, diopside, forsterite, and others. This means that they can be dissolved and be the source of chemical elements and the basis for the newly formed secondary minerals. Thermodynamic calculations are confirmed by X-ray phase analysis of bottom sediments of 30 studied lakes, this analysis has shown that their mineral composition consists of feldspars (mainly albite, orthoclase and microcline), carbonates (calcite and dolomite), X-ray amorphous phase consisting of finely dispersed minerals [15]. Soda and mirabilite are present in the soda Borzinskoye Lake which is high in salinity. A comparative analysis has shown that calcite, feldspar and quartz are present in large quantities in soda lakes compared to chloride lakes.

We have studied the isotopic composition of the sulfur of the dissolved sulfates and sulphides to confirm the main mechanisms responsible for the process controlling the content of the sulfate ion in the lakes. In lake waters, the value of $\delta^{34} \mathrm{~S}$ of dissolved sulfates varies from -8.4 to $27.4 \%$. At average values of $\delta^{34} \mathrm{~S}$, the lightened sulfur composition is characteristic for sulfate (7.7\%) and soda lakes of the subtype II (4.2\%o). Most of the latter lakes are localized within intrusive rocks bearing sulfide mineralization, hence the oxidation of sulphides (mainly pyrite) in the catchment areas leads to the accumulation of sulfate ions with relatively light sulfur in lakes. As a rule, sulfate reduction is relatively poor in these lakes. The heaviest sulfur of sulfate ions (18\%) account for chloride lakes, the value of $\delta 34 \mathrm{~S}(16.8 \%$ ) is a little lower for soda lakes of subtype III. 
In general, the following regularity is revealed: the more reduced sulfur is present in lakes, the lower value of the $\mathrm{SO}_{4} / \mathrm{Cl}$ coefficient is and the isotope-heavier sulfate ions sulfur. Certain isotopic ratios of sulphide sulfur vary from 13.0 in Doroninskoe Lake to $30.8 \%$ in Malye Yakshi Lake. Fractionation of sulfur isotopes is noted in most lakes with a relatively high content of hydrogen sulfide. On average, the fractionation coefficient is $1.023 \%$, with the largest value for soda lakes of subtype III (1.031\%o).

In the arid conditions of a study area, the processes of continental salinization are widely developed; the initial stage is clearly manifested in the formation of soda ground waters with mineralization up to $3.7 \mathrm{~g} / 1$ and $\mathrm{pH}>9$. Under these conditions, evaporative concentration processes ensure progressive accumulation of salts in both ground waters and lakes, which is why our main task was to determine the degree of water evaporation in lakes.

$\mathrm{Cl}$ was used as an indicator of the evaporation degree, because it is the most conservative component, it does not react with formation of secondary minerals in the investigated salinity range, and also it does not participate in sorption and biochemical processes. The degree of lake waters evaporation was calculated according to average content of $\mathrm{Cl}$ in ground waters of a certain basin (the Ingoda River, the Onon River or inland runoff) and its concentration in a particular lake of the same basin.

The obtained data show that the evaporation of lake water varies widely from 2 to 3,744 (average - 280). The minimum value refers to brackish soda lakes, and the maximum value to salt brines of chloride type (Gorbunka Lake). If we compare this indicator with different types of lakes, its minimum values are characteristic for sulfate lakes, and the maximum for chloride lakes. Soda lakes have an intermediate position. The degree of evaporation is on the rise from subtype I to subtype III among soda lakes.

The validity of the data obtained is mainly confirmed by our calculations of the water balance for some lakes. It turned out that the ratio of the input and output components was different in the lakes studied [15]. Thus, in soda lakes (Doroninskoye, Balzoy, Zun-Torey, Bain-Tsagan, Bayan-Bulak, Nozhiy) the ratio of water input and output varies from 0.600.99 and in chloride lakes (Gorbunka, Khilganta, Bilchir-Nuur, Dabas-Nor) it is much lower (0.46-0.52). This situation may beconnected with one more factor: soda lakes are geomorphologically located lower than the chloride ones, hence soda lakes drain the deeper water layers.

Our studies convincingly show that to addition to the water evaporation, there is also interaction with rocks in lakes. The growth of the $\mathrm{pH}$ values in most lakes proves this fact (Table 1). In the case under consideration, $\mathrm{pH}$ growth is impossible without the interaction of water with aluminosilicates.

In a particular case, lake environment is the total result of all the factors mentioned above. One of the most important environment indices is $\mathrm{pH}$; its values indirectly characterize the net effect of these factors. The process of binding of chemical elements with secondary minerals begins in the catchment areas, since all the ground waters are saturated in clay minerals and $\mathrm{Al}$ and Fe hydroxides, and 55\% in calcite and dolomite, less frequently in magnesite. Consequently, the presence of groundwater equilibrium with carbonate and clay minerals within the catchment areas is an important geochemical barrier, which limits the concentration of $\mathrm{Ca}, \mathrm{Mg}, \mathrm{Fe}, \mathrm{K}, \mathrm{Al}$, partially $\mathrm{Si}$ and some microcomponents. The appearance of geochemical barriers in the form of secondary minerals dramatically changes the formation of groundwater composition: the concentration restriction of $\mathrm{Ca}, \mathrm{Mg}$ and $\mathrm{K}$ automatically ensures the growth of $\mathrm{Na}$ contents among the leading cations, which is especially pronounced in ground waters in the Torey basin, i.e. where water exchange is slow [15].

In addition to evaporation, water-rock interaction continues in lakes, but with varying intensity, since the geochemical environment is different in each lake. Of course, the 
sequence of secondary mineral formation varies in different types of lakes and it reaches the last stages not in all lakes. For example, no equilibrium for chlorides has been defined in any lake; for mirabilite, gypsum, soda - in single cases, but in different lakes. However, in general, the direction of this process remains the same, and it serves as the most important process controlling the ability of chemical elements to concentrate. Soda-type lakes are formed as a result of dissolution of some minerals, sedimentation of other minerals, the presence of sulphides in rocks and an oxidizing environment; additional sulfate sources appear to ensure the formation of sulfate-type lakes.

If the evaporation continues, and the increase in the amount of carbonate ions in the lake does not grow or grow slowly because of their binding by the precipitating carbonate minerals, the chlorine content becomes higher, the $\mathrm{pH}$ is less than 9.0, and the type of water changes into a chloride type.

The third main process of lake waters formation is sulfate reduction, which is described above. $\mathrm{H}_{2} \mathrm{~S}$ appears as a result of sulfate reduction in the lakes, this fundamentally changes the nature of geochemical environment from the oxidative to the reducing one and leads to a change in the valence of many elements $(\mathrm{S}, \mathrm{C}, \mathrm{N}, \mathrm{Fe}, \mathrm{Mn}, \mathrm{As}, \mathrm{U}, \mathrm{Mo}, \mathrm{Se}$, and others).They change migratory capacity and, hence, the ability to concentration or binding by secondary minerals.

The geochemical environment formed this way in lakes of different types contributes to the fact that the contents of only some mobile elements increase and accumulate to considerable concentrations under these conditions. F, U, As, Th, REE, Zr, less often Mn, $\mathrm{Zn}, \mathrm{Mo}, \mathrm{Ni}, \mathrm{Cu}$ are concentrated in large amounts in soda lakes, in chloride lakes $-\mathrm{Br}, \mathrm{Sr}$, $\mathrm{Li}, \mathrm{Ba}, \mathrm{Rb}$, in sulfate lakes $-\mathrm{Cu}, \mathrm{Zn}, \mathrm{Ni}$.

\section{Conclusion}

The formation of the chemical composition of salt lakes within a study area is a multifactorial process. In addition to evaporative concentration, there is dissolution of some minerals and formation of others, bacterial reduction of sulfates and oxidation of organic matter and sulphides. The process of soda accumulation in the initial stages of evaporation prevails over the concentration of chlorides, but in the last stages, when a large number of secondary minerals precipitate, the process of chloride concentration becomes more considerable. Sulfates do not readily accumulate like some of the other ions mentioned in this study, because their considerable proportion is reduced to sulphide.

The research was carried out with the financial support of the project RNF [No. 17-17-01158] and RFBR [No. 18-05- 00104].

\section{References}

1. J.H. Van't Hoff, Leningrad: Khimteoret, 345 (1936)

2. N.S. Kurnakov, V.I. Nikolaev, Publishings of Institute of Physics and Chemistry Analysis of the USSR Academy of Sciences 10, 333-366 (1938)

3. N.M. Strakhov, Moscow: USSR Academy of Sciences, 551 (1962)

4. P. Sonnenfeld, Moscow: Mir Publishers, 480 (1988)

5. M. Zheng, Beijing: Science Press., 321 (2014)

A. Droubi, Sci. Ceol., Mem. 46, 177 (1976)

6. M. Gueddari, Sci. Ceol., Mem. 76, 143 (1984)

7. M.N. Kolpakova, S.L. Shvartsev, S.V. Borzenko, V.P. Isupov, S.S. Shatskaya, IOP Conference Series: Earth and Environmental Science. 33 (1), 012007 (2016) 
8. S.L. Shvartsev, M.N. Kolpakova, V.P. Isupov, A.G. Vladimirov, S. Ariunbileg, Int. 52 (5). 388-403 (2014)

9. V.D. Strakhovenko, B.L .Shcherbov, I.N. Malikova, Y.S. Vosel, Geol. and Geophys. 51 (11), 1501-1514 (2010)

10. J.K. Warren, Prentice-Hall, Englewood Cliffs 29 (5), 548-556 (1989)

11. A.V. Ivanov, Vladivostok: FESU. 128 (1977) (in Russian)

12. E.V. Sklyarov, O.A. Sklyarova, Y.V. Menshagin, M.A. Danilova, Geography and natural resources 4, 29-39 (2011)

13. L.V. Zamana, S.V Borzenko, 31 (4), 370-376 (2010)

14. S.V. Borzenko, Dissertation, Tomsk Polytechnic University (2018)

15. O.A. Alekin, Gidrometeo Publishing House, Leningrad. 443 (1970) (in Russian)

16. M.G. Valyashko, Moscow: Moscow State University, 398 (1962)

17. M.A. McCaffrey, B. Lazar, H.D. Holland, J. Sedim. Petrol. 57, 928-937 (1987)

18. S.L. Shvartsev, Geochem. Int. 28 (2), 260-276 (2008) 